\title{
スパッタ法による二酸化チタン系透明導電膜の成膜技術と特性
}

山田 直臣 $* 1 \cdot$ 一杉 太郎*1,*2,†・長谷川哲也*1,*2

\section{Sputter Deposition of Anatase Titanum Dioxide Transparent Conducting Films}

\author{
Naoomi YAMADA*1, Taro HITOSUGI*1,*2, and Tetsuya HASEGAWA*1,*2 \\ ${ }^{* 1}$ Kanagawa Academy of Science and Technology (KAST), 3-2-1 Sakado, Takatsu-ku, Kawasaki-shi, Kanagawa 213-0012, Japan \\ ${ }^{* 2}$ Department of Chemistry, University of Tokyo, 7-3-1 Hongo, Bunkyo-ku, Tokyo 113-0013, Japan
}

(Received January 9, 2008, Accepted April 5, 2008)

\begin{abstract}
We report recent progress on sputter-deposition of $\mathrm{Ti}_{0.94} \mathrm{Nb}_{0.06} \mathrm{O}_{2}$ polycrystalline (poly-TNO) thin films as ITO-alternative transparent conductor. In order to achieve low resistivity $(\rho)$ in TNO, it is necessary to introduce oxygen deficiencies into anatase phase. However, growth of poly-TNO films on glass under relatively reducing atmosphere tends to stabilize the rutile phase with higher resistivity. We overcame this difficulty by developing a bi-layer technique using a TNO seed-layer, which prevents the formation of the rutile phase even under reducing deposition conditions. As a result, we succeeded in directly fabricating poly-TNO films with $\rho$ of $\sim 1$ $\times 10^{-3} \Omega \mathrm{cm}$ and visible transmittance of $60 \sim 80 \%$, although we still need to further improve these properties towards practical applications. By comparing carrier transport properties between poly-TNO films obtained by different synthesis routes, we discuss on material parameters that govern resistivity of poly-TNO films.
\end{abstract}

\section{1.はじめに}

可視光に対して透明かつ金属的な電気伝導性を示す透明導 電体は，現在のオプトエレクトロニクスにおいて重要な役割 を担っている，たとえば，平面型ディスプレイ（FPD）や 太陽電池, 各種発光デバイス等の透明電極として不可欠な存 在である ${ }^{1)}$. 透明導電体として最もよく知られているのが, $\mathrm{Sn}$ をドープした $\mathrm{In}_{2} \mathrm{O}_{3}$ (ITO) である. ITO 薄膜は低い抵 抗率 $\rho\left(\sim 2 \times 10^{-4} \Omega \mathrm{cm}\right)$ と優れた可視光透過率 $T_{\text {vis }}(\sim 80$ \%）を容易に両立できるため, 現在最も広く用いられてい る1). しかしながら, 近年, ITOの主要構成元素である In の枯渴が懸念されている. その一方, FPDの普及が急速に 進んで打り, 今後も透明導電体の需要は増え続けるものと予 測される。したがって，Inのような希少金属を含まない 「脱 In」の透明導電体の探索が緊急の課題になっている.

このような背景の中, 我々の研究グループは, パルスレー ザー堆積法 (PLD 法)により作製した Nb あるいは Taをドー プしたアナターゼ型の $\mathrm{TiO}_{2}$ エピタキシャル薄膜が優良な透 明導電体であることを見出した ${ }^{2-5)}$. その抵抗率 $\rho$ は $2.3 \times$ $10^{-4} \Omega \mathrm{cm}$, 内部透過率（反射による効果を差し引いた, 媒 体内に抢ける純粋な透過率）は可視光領域において $97 \%$ 以 上であり，ITOに比肩する．このことは, 我々の研究グ ループ以外の研究機関でも確認されており, PLD 法6,7)やス パッタ法8)によるエピタキシャル薄膜で低い $\rho$ と高い透明性 が得られている. 最近では, ガラス上に形成したアナターゼ 型の $\mathrm{Nb}$ ドープ $\mathrm{TiO}_{2}$ ( $\mathrm{TNO}$ ) 多結晶薄膜でも, $10^{-4} \Omega \mathrm{cm}$ 台の低い $\rho$ と高い可視光透過率 $T_{\mathrm{vis}}$ が得られることがわか

*1 財)神奈川科学技術アカデミー（KAST）（†213-0012 神奈川 県川崎市高津区坂戸 3-2-1)

*2 東京大学大学院理学系研究科化学専攻（干113-0013 東京都文 京区本郷 7-3-1)

$\uparrow$ 現所属: 東北大学原子分子材料科学高等研究機構 (广980-8577 仙台市青葉区片平 $2-1-1$ )
ってきた ${ }^{9,10)}$.このように, TNO は透明導電体として高い ポテンシャルを有している，さらに， $\mathrm{TiO}_{2}$ は地殼中に豊富 に存在しているので元素枯渴の懸念がなく, 安価なばかりで なく, 毒性の心配もない. それゆえ, $\mathrm{TiO}_{2}$ を母材とした透 明導電膜が開発できれば，ITOの有力な代替候補になりう る.

我々は, TNOの高いポテンシャルに着目し, 多結晶薄膜 を透明導電体として実用化することに取り組んでいる.これ までの取り組みの中で, 低い $\rho$ 抵抗率を有する TNO 多結晶 薄膜を得るためには, アモルファスの TNO 薄膜をガラス上 に形成し，それを還元性䨌囲気でアニールして結晶化させる ことが有効であることを報告してきた ${ }^{9,10)}$ 。例えば，PLD 法 でアモルファス薄膜を作製した場合には $\rho=4.6 \times 10^{-4} \Omega$ $\mathrm{cm}^{9)}$, スパッタ法を用いた場合には $\rho=6.5 \times 10^{-4} \Omega \mathrm{cm}^{11)}$ が 得られている。透明導電体としての実用化の目安は $\rho<5 \times$ $10^{-4} \Omega \mathrm{cm}$ といわれている12). したがって, 上記の $\rho$ は実用 特性に迫る值であり, アモルファス薄膜を還元性䨌囲気下で 結晶化させる手法が極めて有効な手法であることがわかる. 現在, よりいっそうの低抵抗化を目指して, 成膜とアニール の両プロセスを改良することに取り組んでいる.

上記に加えて, 還元性アニールすることなく, as-depositedの多結晶薄膜で高い透明導電性を得ることにも取り組ん でいる．これまで as-depositedの多結晶薄膜で透明導電性を 実現することは試みられてきたが，低い $\rho$ は得られていな い. PLD 法を用いた場合で $\rho=1.5 \times 10^{-1} \Omega \mathrm{cm}^{13)}$ ，スパッ タ法の場合では $\rho \sim 1.7 \times 10^{-2} \Omega \mathrm{cm}^{14)}$ あるいは $1.9 \times 10^{3} \Omega$ $\mathrm{cm}^{15)}$ という報告がなされている。しかし，これらの 2 はい ずれもアモルファス薄膜をアニールする手法で作製した多結 晶薄膜と比して $2 \sim 6$ 桁程度高い. ごく最近, 我々は, アナ ターゼ型構造を有する「TNO シード層」をガラス上に形成 し，その上に還元条件（低酸素分圧）でTNO 薄膜を形成す ると，これまでの報告よりも $\rho$ を 1 桁以上低くできること を見出した $\left(\rho \sim 1.2 \times 10^{-3} \Omega \mathrm{cm}\right)$. 実用レベルの $\rho$ と比べ 
てまだ開きはあるものの, as-deposited 多結晶薄膜で低い $\rho$ を実現できるきっかけは得られたと考えている。本稿では， この TNO シード層を用いた as-deposited 多結晶薄膜の成膜 技術について紹介する.

\section{2. アナターゼ型 $\mathrm{TiO}_{2}$}

本稿で紹介するスパッタ成膜技術では, $\mathrm{TiO}_{2}$ の結晶構造 を制御することに主眼がある。ここでは， $\mathrm{TiO}_{2}$ がとり得る 結晶構造, ならびにそのスパッタ条件依存性について簡単に 紹介する.

$\mathrm{TiO}_{2}$ は複数の結晶構造をとり得るが, 実用上重要な結晶 型はアナターゼ型 $\mathrm{TiO}_{2}(a=b=0.3782 \mathrm{~nm}, c=0.9502 \mathrm{~nm})$ とルチル型 $\mathrm{TiO}_{2}(a=b=0.4584 \mathrm{~nm}, c=0.2953 \mathrm{~nm})$ である (今後それぞれ，アナターゼ，ルチルと呼ぶ) ${ }^{16)}$. 熱力学的 な最安定相はルチルであり, アナターゼは準安定相である. アナターゼとルチルの結晶構造を, それぞれ, Fig. 1 (a) と (b)に示す．この二つの結晶構造は $\mathrm{TiO}_{6}$ 八面体構造のネッ トワークを考えると理解しやすい. アナターゼは八面体の 4 つの稜を, ルチルは 2 つ稜を共有してネットワークを作 っている. アナターゼでは共有している稜の数が多いため, 伝導帯を形成する $\mathrm{Ti}$ の $3 d$ 軌道同士の重なりが大きく, 電 気伝導に有利であると定性的に予測できる. 実際, 伝導帯の

(a)

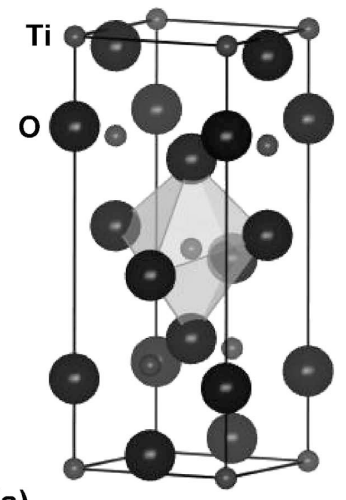

Fig. 1 Crystal structure of (a) anatase- and (b) rutile-type $\mathrm{TiO}_{2}$.

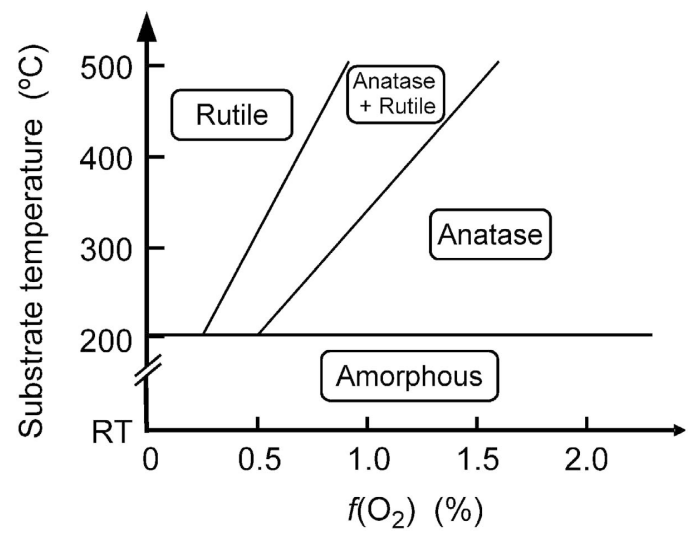

Fig. 2 Relationship between sputter-deposition parameters (substrate temperature and $\mathrm{O}_{2} /\left(\mathrm{Ar}+\mathrm{O}_{2}\right)$ flow ratio) and crystal structure of TNO polycrystalline films on glass.
有効質量は, アナターゼが $0.5 \sim 1.5 m_{0}\left(m_{0}\right.$ は自由電子の質 量) ${ }^{17,18)}$ と比較的小さいのに対し, ルチルの場合は $20 m_{0}{ }^{19)}$ と 大きい. 両者のうちで透明導電性はアナターゼでのみ発現す る.

アナターゼ多結晶薄膜を物理的気相法で作製するには，基 板温度をやや低くして, 高めの酸素分圧（酸化条件）で成膜 することが好ましいことが知られている20,21). Fig. 2 に， ガラス上へ $\mathrm{Ti}_{0.94} \mathrm{Nb}_{0.06} \mathrm{O}_{2}$ ターゲットを用いた $\mathrm{RF}$ マグネト ロンスパッタ法で TNO 薄膜を作製したときの, 成膜パラ

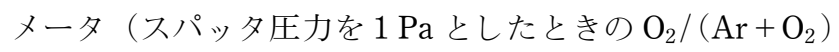
流量比 $f\left(\mathrm{O}_{2}\right)$ と基板温度）と薄膜の結晶構造の関係を示す. この図から，低酸素分圧（還元条件）で成膜した場合には， 低抵抗化に不利なルチルが生成することがわかる。しかし， アナターゼに高い導電性を付与するには酸素欠損を多量に導 入 (強還元) する必要がある9,10,13)ので, 還元条件, すなわ ちルチルが生成しやすい条件でアナターゼ型多結晶を成膜し なければならない,したがって, 透明導電性の TNO 多結晶 薄膜を得るには, 低酸素分圧条件でいかにして強還元された アナターゼを作るか，ということに焦点が絞られる．

\section{3. シード層を用いた強還元アナターゼ薄膜の成 膜}

$\mathrm{TNO}$ 薄膜の成膜には, RF マグネトロンスパッタリング 法を用いた. ターゲットには, $\mathrm{Ti}_{0.94} \mathrm{Nb}_{0.06} \mathrm{O}_{2}$ 焼結体ターゲ ットを用い，基板には無アルカリガラスと $\mathrm{LaAlO}_{3}$ (LAO) （100）基板を使用して多結晶薄膜とエピタキシャル薄膜を同 時に成膜した. 成膜圧力は $1 \mathrm{~Pa} と し$, スパッタガスには $\mathrm{Ar}$ と $\mathrm{O}_{2}$ の混合ガスを用いた. $\mathrm{Ar}$ と $\mathrm{O}_{2}$ の流量比 $f\left(\mathrm{O}_{2}\right)$ は, 0 〜 $1 \%$ の間で変化させた. また, 基板温度 $T_{\mathrm{s}}$ に関しては, ガラス上への適用を考えて $250 \sim 400^{\circ} \mathrm{C}$ 範囲とした.

Fig. 3(a)と（b)は，それぞれ， LAO (100)上とガラス上へ， $T_{\mathrm{s}}=400^{\circ} \mathrm{C}, f\left(\mathrm{O}_{2}\right)=0.35 \%$ で同時成膜した試料の $\mathrm{X}$ 線回折 パターンである. LAO 上ではアナターゼ型 TNO がエピタ キシャル成長して抢り, $\rho=3.6 \times 10^{-4} \Omega \mathrm{cm}$ という低い值が 得られる. それに対して, ガラス上では, Fig. 2 から推測で きるとおり, ルチル型多結晶薄膜が生成しており, その $\rho$ は $1.7 \times 10^{0} \Omega \mathrm{cm}$ で, エピタキシャル薄膜と比して約 4 桁も 高くなる. ガラス上で $\rho$ が高くなるのは, 電気伝導に不利 なルチル型構造になることが原因である. 一方の LAO 基板 を用いた場合には，基板の拘束力によってルチル型構造にな るのを防ぎ, 強く還元されたアナターゼ型構造が実現できて いる. この結果, LAO 基板上では低い $\rho$ を得ることができ るものと考えられる. したがって, ガラス表面にアナターゼ を安定化させる拘束力を持たせることができれば， $\rho$ の低い 強還元アナターゼ型多結晶薄膜を実現できるものと推察され る.

そこで次に，いかにガラス基板表面にアナターゼを安定化 させる拘束力を持たせるかについて考えよう.Fig. 2 を見る とわかると抢り， $T_{\mathrm{s}}$ をやや低くし， $f\left(\mathrm{O}_{2}\right)$ を増した酸化条 件にすればアナターゼ型多結晶をガラス上に作製することが できる．たとえば， $T_{\mathrm{s}}$ を $250^{\circ} \mathrm{C}$ な゙低下させて，かつ， $f\left(\mathrm{O}_{2}\right)$ を $1 \%$ まで増やすと, 結晶性の良好なアナターゼ型の 
多結晶薄膜が得られる (Fig. 3(c))。ただし，この場合に は, 得られる薄膜は還元不足であるので $\rho$ は高くなってし まう $\left(\rho \sim 10^{2} \Omega \mathrm{cm}\right)$. 我々は, この酸化条件で形成した TNO をシード層として用いれば，ガラス基板表面にアナ ターゼを安定化させる拘束力を持たせることができると考え た。すなわち，TNO シード層を形成したガラス基板上へ， 還元条件でTNO の成膜を行えば, 強還元アナターゼがシー ド層に対してエピタキシャル的に成長することが期待できる (Fig. 4).

そこで, Fig. 4 に示した通り, ガラス上に $30 \mathrm{~nm}$ のシー ド層を $T_{\mathrm{s}}=250^{\circ} \mathrm{C}, f\left(\mathrm{O}_{2}\right)=1 \%$ (酸化条件) で形成し，そ の上に $T_{\mathrm{s}}=400^{\circ} \mathrm{C}, f\left(\mathrm{O}_{2}\right)=0.35 \%$ (エピタキシャル薄膜の 場合に最も低い $\rho$ が得られる条件）で強還元層を膜厚 150 $\mathrm{nm}$ になるように膜厚形成した（以下， 2 層 TNO 多結晶薄 膜)。XRD 測定の結果, 狙い通りにアナターゼ型の多結晶 が得られることが確認できた（Fig. $3(\mathrm{~d}))$ ）この試料の $\rho$ は $8.2 \times 10^{-2} \Omega \mathrm{cm}$ であり, 先述のシード層を形成していない 場合 $\left(\rho=1.7 \times 10^{\circ} \Omega \mathrm{cm}\right)$ と比べて 1 桁以上低い值が得られ た。しかし,この $\rho$ では実用的な透明導電体としては不十 分である.より低い $\rho$ を得るため, さらに強還元層の成膜

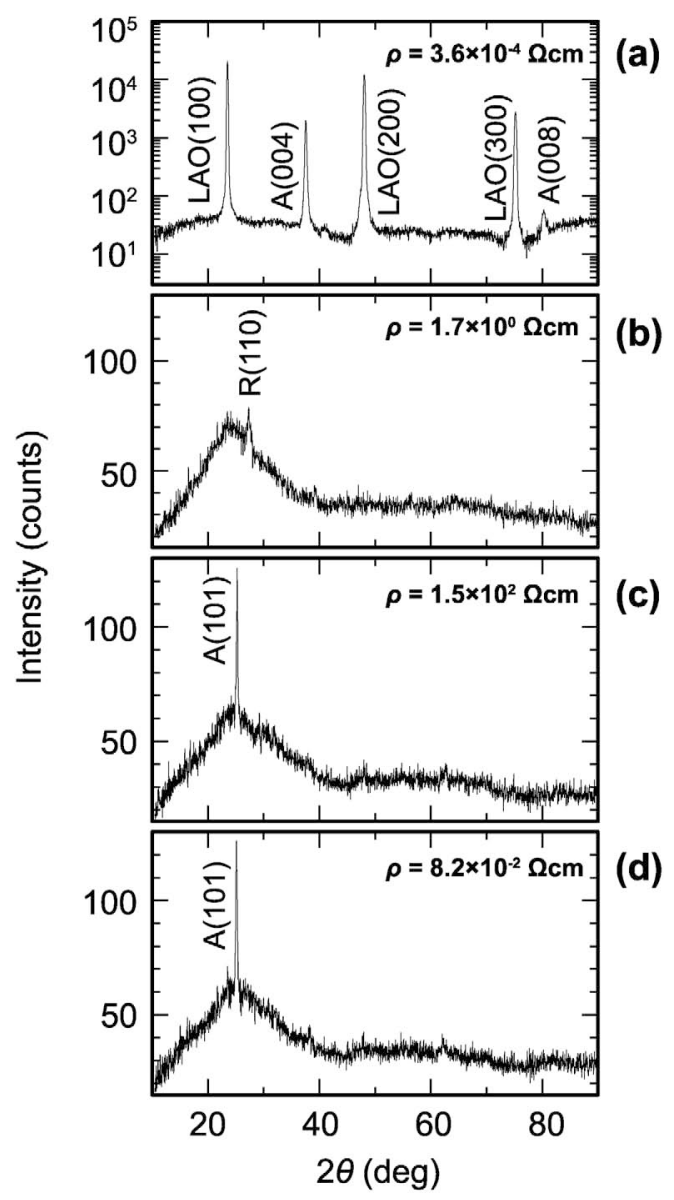

Fig. 3 X-ray diffraction patterns of (a) TNO epitaxial film on LAO (100) substrate $\left(T_{\mathrm{s}}=400^{\circ} \mathrm{C}\right.$ and $\left.f\left(\mathrm{O}_{2}\right)=0.35 \%\right)$, (b) TNO polycrystalline film on glass $\left(T_{\mathrm{s}}=400^{\circ} \mathrm{C}\right.$ and $f\left(\mathrm{O}_{2}\right)=$ $0.35 \%)$, (c) TNO polycrystalline film on glass $\left(T_{\mathrm{s}}=250^{\circ} \mathrm{C}\right.$ and $f\left(\mathrm{O}_{2}\right)=1.0 \%$ ), and (d) bi-layer TNO film on glass. The bi-layer TNO film was fabricated according to the procedure as shown in Fig. 4.
条件を最適化した。

\section{4. 成膜条件の最適化}

ガラス上の 2 層 TNO 多結晶薄膜のキャリア輸送特性は, 強還元層成膜時の $f\left(\mathrm{O}_{2}\right)$ に強く依存する. 室温における $\rho$, キャリア濃度 $\left(n_{\mathrm{e}}\right)$, そして Hall 移動度 $\left(\mu_{\mathrm{H}}\right)$ を強還元層 成膜時の $f\left(\mathrm{O}_{2}\right)$ に対してプロットしたものが Fig. $5(\mathbf{a}) \sim$ (c)である．比較として，LAO 上に単層で作製した薄膜につ いてもプロットした．この図を見ると，LAO 上とガラス上 $\left(2\right.$ 層 TNO 多結晶薄膜) とで, $f\left(\mathrm{O}_{2}\right)$ に対する $\rho$ の振る舞

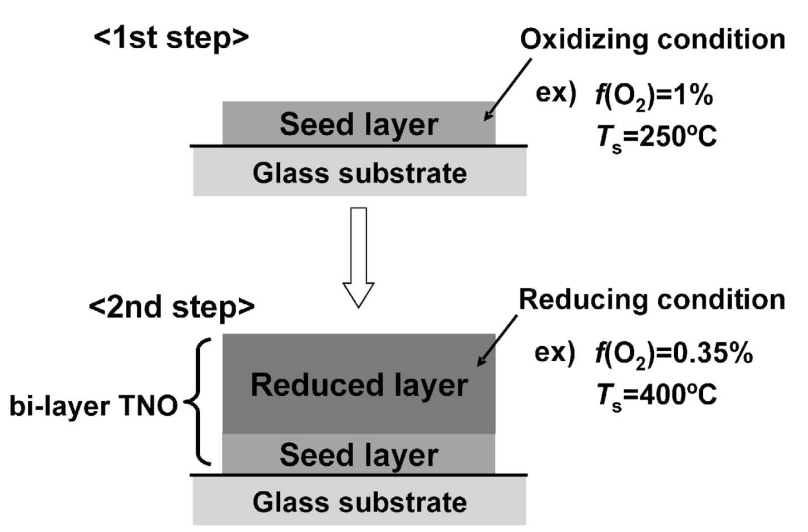

Fig. 4 Schematic illustration of bi-layer deposition technique.

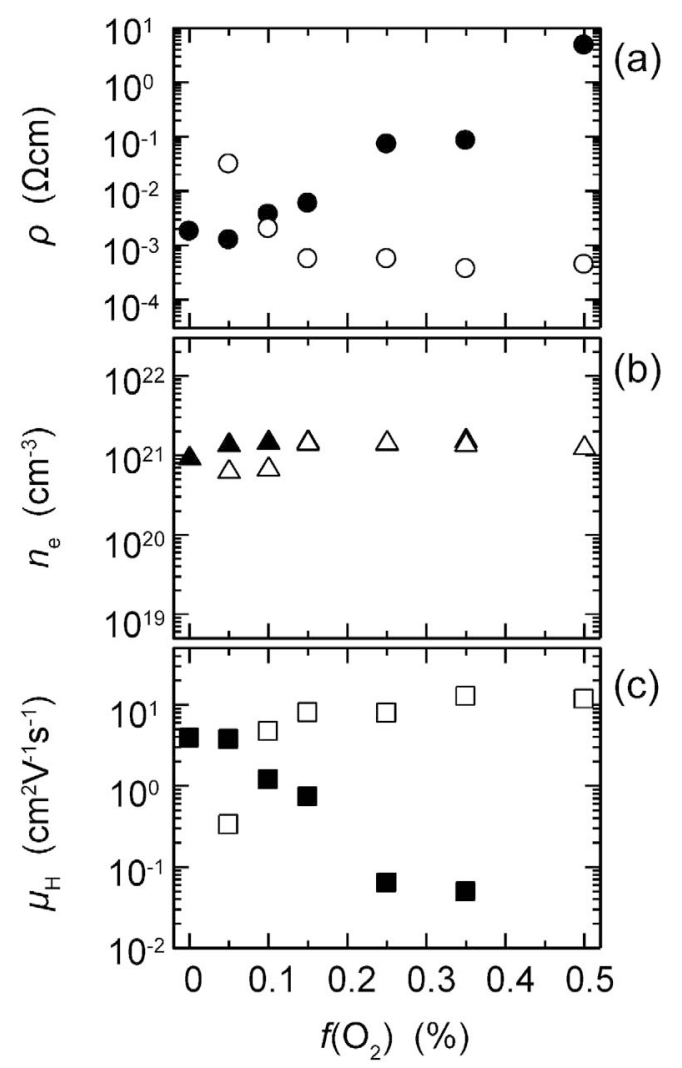

Fig. 5 Carrier transport properties at room temperature, (a) resistivity $\rho$, (b) carrier density $n_{\mathrm{e}}$ and (c) Hall mobility $\mu_{\mathrm{H}}$, of bi-layer TNO films on glass (open symbols), as functions of $f\left(\mathrm{O}_{2}\right)$ during deposition of reduced layer. Also, $\rho, n_{\mathrm{e}}$ and $\mu_{\mathrm{H}}$ of single-layer TNO films on LAO (100) substrate (closed symbols) are plotted for comparison. 
いがまったく異なっていることがわかる.

2 層 TNO 多結晶薄膜では, 強還元層成膜時の $f\left(\mathrm{O}_{2}\right)$ が 減少するにともない， $\rho$ は急激に低くなる. $f\left(\mathrm{O}_{2}\right)=0.05 \%$ のときに $\rho$ は最も低くなり, $\rho=1.2 \times 10^{-3} \Omega \mathrm{cm}$ が得られ る. 酸素導入量をさらに減少させて $f\left(\mathrm{O}_{2}\right)=0 \%$ にすと $\rho$ はやや上昇する. $f\left(\mathrm{O}_{2}\right)=0 \%$ 屯で減少させると, アナター ゼとルチルの混相多結晶薄膜になることが原因である．ここ で得られた $\rho$ 最低值は，これまで報告されてきたasdeposited 多結晶薄膜のものと比べて $1 \sim 2$ 桁低い. 実用レ ベルの $\rho$ とはまだ開きがあるが，ガラス上の as-deposited 多結晶薄膜において低い $\rho$ を実現するためのきっかけは得 られたと考えている.

他方, LAO 基板上の薄膜においては, $\rho$ の $f\left(\mathrm{O}_{2}\right)$ 依存性 は，ガラス上の場合とはまったく異なる．ガラス上では， $f\left(\mathrm{O}_{2}\right)=0.05 \%$ 近傍の狭い領域でしか低い $\rho$ が得られないの に対して, LAO 上では $f\left(\mathrm{O}_{2}\right)=0.15 \sim 0.5 \%$ の比較的広い範 囲で $\rho<5 \times 10^{-4} \Omega \mathrm{cm}$ という低い $\rho$ のエピタキシャル薄膜 が得られる. $f\left(\mathrm{O}_{2}\right) \leq 0.1 \%$ では, エピタキシャル薄膜が得 られず，ルチルとアナターゼが混在した多結晶になるので $\rho$ は大きくなってしまう. $\rho$ が最も低くなる $f\left(\mathrm{O}_{2}\right)$ (以下, 最 適 $\left.f\left(\mathrm{O}_{2}\right)\right)$ は, 先述のと抢り $f\left(\mathrm{O}_{2}\right)=0.35 \%$ ときである $\left(\rho=3.6 \times 10^{-4} \Omega \mathrm{cm}\right) . \mathrm{LAO}$ 上とガラス上とで $\rho$ の $f\left(\mathrm{O}_{2}\right)$ 依存性が異なるのは, 以下で述べるように, $\mu_{\mathrm{H}}$ の $f\left(\mathrm{O}_{2}\right)$ 依 存性が大きく異なるからである.

次に, $n_{\mathrm{e}}$ と $\mu_{\mathrm{H}}$ の $f\left(\mathrm{O}_{2}\right)$ 依存性について比較してみよう. Fig. 5(b)を見るとわかるように, LAO 上とガラス上とで, $n_{\mathrm{e}}$ にはほとんど差がない。また，いずれの場合においても $f\left(\mathrm{O}_{2}\right)$ 依存性は小さい. 一方, $\mu_{\mathrm{H}}$ は, $f\left(\mathrm{O}_{2}\right)$ に強く依存す る (Fig. 5(c)).したがって, 先述した, $\rho$ の $f\left(\mathrm{O}_{2}\right)$ 依存性 は， $\mu_{\mathrm{H}}$ の $f\left(\mathrm{O}_{2}\right)$ 依存性で決まっている. ガラス上の 2 層 TNO 多結晶薄膜では $f\left(\mathrm{O}_{2}\right)$ を $0.35 \%$ から $0.05 \%$ をで減らす と, $\mu_{\mathrm{H}}$ は 2 桁以上の増大を示す. それに対し, LAO上で は，エピタキシャル成長する $f\left(\mathrm{O}_{2}\right)$ の範囲 $(\geq 0.15 \%)$ で は， $\mu_{\mathrm{H}}$ の $f\left(\mathrm{O}_{2}\right)$ 依存性はそれほど大きくはない。なぜこの ような違いが生じるのであろうか？

今のところ, 直接的な証拠は得られていないが, 以下のよ うに推測している. 本研究で得られた多結晶薄膜では, 後述 するように, キャリアの輸送が粒界散乱により支配されてい ると予想される. 多結晶薄膜の成膜では, $f\left(\mathrm{O}_{2}\right)$ の増加に ともなって, 結晶中に取り込まれる酸素だけでなく, 粒界に 吸着する酸素が増大し, 粒界ポテンシャルを押し上げるであ ろう. その結果, $\mu_{\mathrm{H}}$ が $f\left(\mathrm{O}_{2}\right)$ の増大にともなって減少する ものと考えられる. またエピタキシャル薄膜では, 多結晶薄 膜に比べて粒界が少なく, 結晶方位が揃っているので, 粒界 がキャリア輸送へ及ぼす影響が相対的に小さいと考えられ る. そのため, $\mu_{\mathrm{H}}$ の $f\left(\mathrm{O}_{2}\right)$ 依存性が小さいものと思われる.

\section{5. キャリア輸送特性}

作製方法が異なる TNO 薄膜の輸送特性を比較してみよ う. 比較するのは, 本研究で得られた最も低い $\rho$ を有する 2 層 TNO 多結晶薄膜とエピタキシャル薄膜, そして, 我々が これまで報告してきた, スパッタ法で成膜したアモルファス
薄膜を真空アニールによって結晶化させた多結晶薄膜（以 下，アニール多結晶薄膜) 11 である.

Fig. 6(a)〜 (c) は， $\rho, n_{\mathrm{e}}$ そして $\mu_{\mathrm{H}}$ を温度に対してプロッ トした図である. Fig. 6(a)から, 作製方法によって $\rho$ が大 きく異なることがわかる， $n_{\mathrm{e}}$ に関しては，作製方法によっ て差はなく, 1.5〜 $1.7 \times 10^{21} \mathrm{~cm}^{-3}$ の範囲にある (Fig. 6(b)). $1 \times 10^{21}$ 台の高い $n_{\mathrm{e}}$ が，作製方法に依らず，容易に得られる ことは, 他の透明導電体にはない TNO の著しい特徵であ る.作製方法によって顕著な差が見られるのは， $\mu_{\mathrm{H}}$ である (Fig. 6(c)). エピタキシャル薄膜が最も大きく（300 K に 扔いて $\left.13 \mathrm{~cm}^{2} \mathrm{~V}^{-1} \mathrm{~s}^{-1}\right)$, その次がアニール多結晶薄膜 (300 $\mathrm{K}$ において $\left.5.8 \mathrm{~cm}^{2} \mathrm{~V}^{-1} \mathrm{~s}^{-1}\right)$ であり, 最も小さいのが本研 究の 2 層 TNO 多結晶薄膜 $\left(300 \mathrm{~K}\right.$ において $\left.3.6 \mathrm{~cm}^{2} \mathrm{~V}^{-1} \mathrm{~s}^{-1}\right)$ である.上述した $\rho$ の差は，この $\mu_{\mathrm{H}}$ の差が反映されている. 2 層 TNO 多結晶薄膜において, さらに低い $\rho$ を得るために は, $\mu_{\mathrm{H}}$ の向上が必要不可欠である.

2 層 TNO 多結晶薄膜とアニール多結晶薄膜とで, 同じ多 結晶薄膜であるにもかかわらず， $\mu_{\mathrm{H}}$ に大きな差がある。例 えば $300 \mathrm{~K}$ において，2 層 TNO 多結晶薄膜の $\mu_{\mathrm{H}}\left(3.6 \mathrm{~cm}^{2}\right.$ $\left.\mathrm{V}^{-1} \mathrm{~s}^{-1}\right)$ は, アニール多結晶の $\mu_{\mathrm{H}}\left(5.8 \mathrm{~cm}^{2} \mathrm{~V}^{-1} \mathrm{~s}^{-1}\right)$ の半 分程度である. また, 2 層 TNO 多結晶薄膜とアニール多結 晶薄膜とで, $\mu_{\mathrm{H}}$ の温度依存性が異なっている. $\mu_{\mathrm{H}}$ が比較的 大きいアニール多結晶薄膜では, 温度の低下にともなって

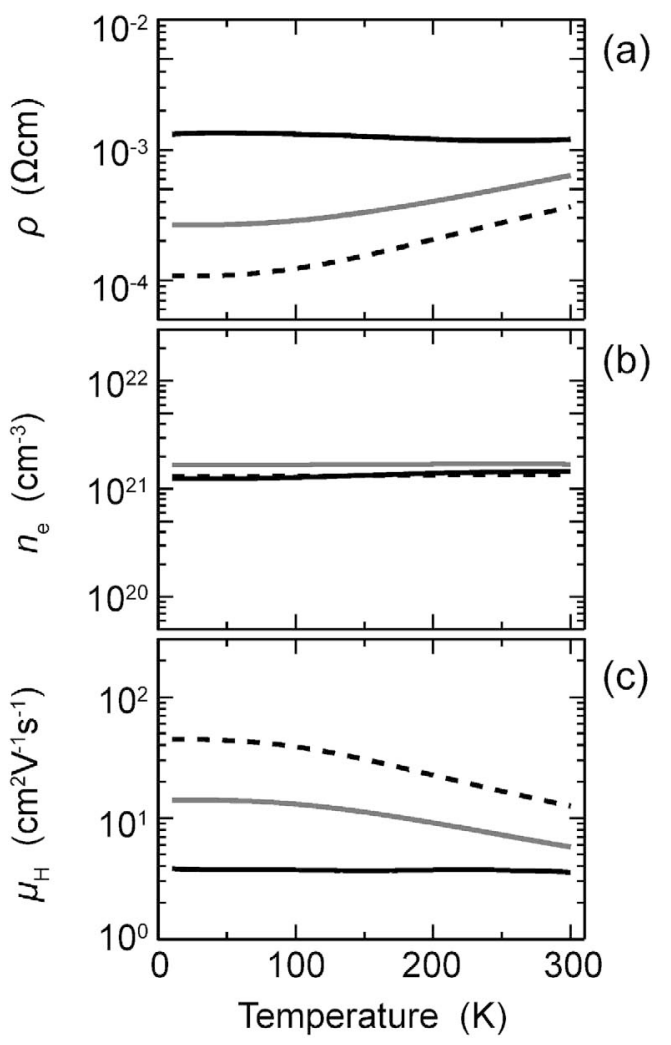

Fig. 6 Temperature dependence of (a) resistivity $\rho$, (b) carrier density $n_{\mathrm{e}}$ and (c) Hall mobility $\mu_{\mathrm{H}}$ of TNO thin films fabricated by various techniques. Black lines are for bi-layer TNO polycrystalline film, gray lines are for TNO polycrystalline film fabricated by annealing of sputtered amorphous phase, and dashed lines are for sputter-deposited epitaxial film on LAO substrate. 
$\mu_{\mathrm{H}}$ は増大する (エピタキシャル薄膜と同様の傾向).このこ とから,アニール多結晶薄膜に抽ては, PLD 法による $\mathrm{TNO}$ エピタキシャル薄膜 ${ }^{18)}$ 同様, 光学フォノン散乱がキャ リア輸送を支配していると考えられる。 それに対して，2 層 TNO 多結晶薄膜では, 温度の低下にともなう $\mu_{\mathrm{H}}$ の増大が 観察されない。アニール多結晶薄膜とは支配的な散乱機構が 異なっている可能性が高い。これらの違いは何に起因するの であろうか？

この違いの原因を調べるために，アニール多結晶薄膜と 2 層 TNO 多結晶薄膜の組織観察を行った. アナターゼの屈折 率は異方性を有するので，結晶粒が十分に大きい多結晶薄膜 であれば，偏光顕微鏡によって組織観察をすることが可能で ある.Fig. 7 (a) と（b)は，それぞれ，アニール多結晶薄膜と 2 層 TNO 多結晶薄膜の偏光顕微鏡像である.アニール多結 晶薄膜では，結晶粒を明膫に観察することができる．これか ら見積もった結晶粒のサイズは $10 \mu \mathrm{m}$ 程度である。一方, Fig. 7 (b)の 2 層 TNO 多結晶薄膜では，結晶粒が非常に小 さく，偏光顕微鏡によって観察することができない．原子間 力顕微鏡 $(\mathrm{AFM})$ 観察によると（Fig. 7 (b) 挿図 ), 2 層 TNO 多結晶薄膜の結晶粒サイズは $<1 \mu \mathrm{m}$ である。つまり, 本研究で得られた 2 層 TNO 多結晶薄膜は，アニール多結晶 薄膜と比べて, 結晶粒径が約 1 桁小さい $\left(\mu_{\mathrm{H}}\right.$ は約 $\left.1 / 2\right)$. し たがって，多結晶薄膜のキャリア輸送には粒界散乱が寄与し て抢り, 結晶粒径の小さい 2 層 TNO 多結晶薄膜では, 粒界 散乱の寄与が大きくなるために $\mu_{\mathrm{H}}$ が小さくなると推察され る。また，粒界散乱が熱電子放出型22)であるとすれば，粒

(a)

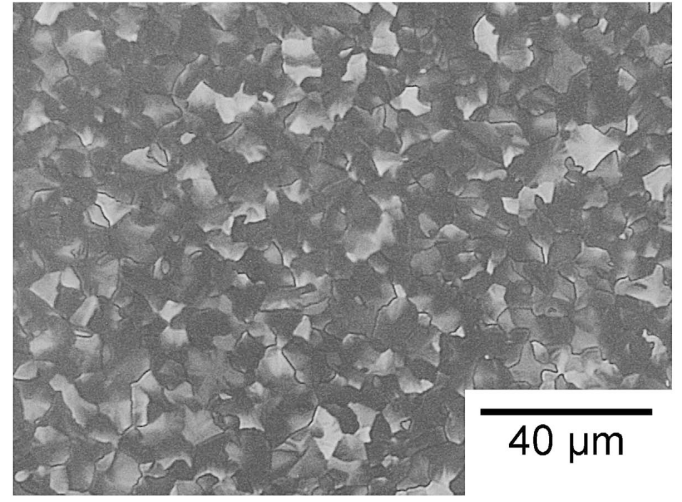

(b)

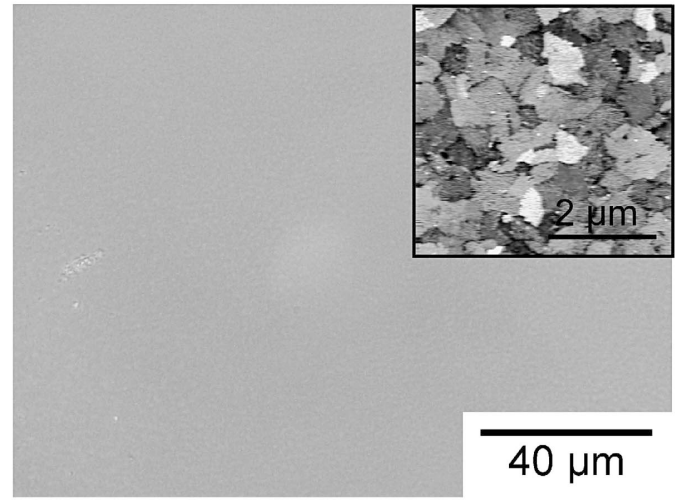

Fig. 7 Polarized optical micrograph images of TNO polycrystalline films fabricated by (a) annealing sputter-deposited amorphous film and (b) bi-layer deposition technique.
界散乱による移動度は熱活性型になるので, 先述の光学フォ ノン散乱（移動度が負の温度係数を有する）と重畳した場合 には，移動度の温度依存性が小さくなると考えられる．これ は， 2 層 TNO 多結晶薄膜の $\mu_{\mathrm{H}}$ がほとんど温度依存性を示 さない（Fig. 6 (c)）ことと矛盾しない. 2 層 TNO 多結晶薄 膜の移動度を向上させるために, 結晶粒径を大きくして粒界 の影響を小さくすることが今後の課題であると考えている.

\section{6. 光 学 特 性}

Fig. 8 (a) は, 本研究で得られた最も低い抵抗率（ $\rho=1.2$ $\left.\times 10^{-3} \Omega \mathrm{cm}\right)$ を有する多結晶薄膜の透過率 $T$ と反射率 $R$ で ある．可視光領域では，透過率60～80\%，反射率10３0\% であり，可視光透過率は，ITO 薄膜と比較するとやや低い 值を示す。これは, 可視光領域における TNO 薄膜の屈折率 $\left(\sim 2.4^{23)}\right)$ が ITO の屈折率 $\left(\sim 2.0^{24)}\right)$ よりも大きいため反 射率が高くなることに起因している.しかし，100-T-R で見積もった吸収は可視光領域において $10 \%$ 以下であり, 透明性は十分に確保できている（Fig. 8(b)). TNO 薄膜の 屈折率が高いということは, ガラス基板（屈折率～1.5）上 では干渉色が生じやすいというデメリットになりうる。しか しながら，例えば化合物半導体などの高屈折基材上に形成す る場合には屈折率のマッチングが良く，透過率を上げること が可能であると考えられる。このような観点から，TNO 薄 膜を $\mathrm{Si}$ 系薄膜太陽電池に用いる検討もなされている25).

\section{7. 今後の展望}

実用化研究の観点からの最重要課題は，移動度を向上させ て低抵抗率化をはかり，実用的な指標である $\rho<5 \times 10^{-4} \Omega$ $\mathrm{cm}$ を達成することである，そのためには，結晶粒径を増大 させて粒界散乱の寄与を低減することが重要である．大きな 結晶粒を実現できるプロセスの開発を中心に据えて研究を行 っていきたい.

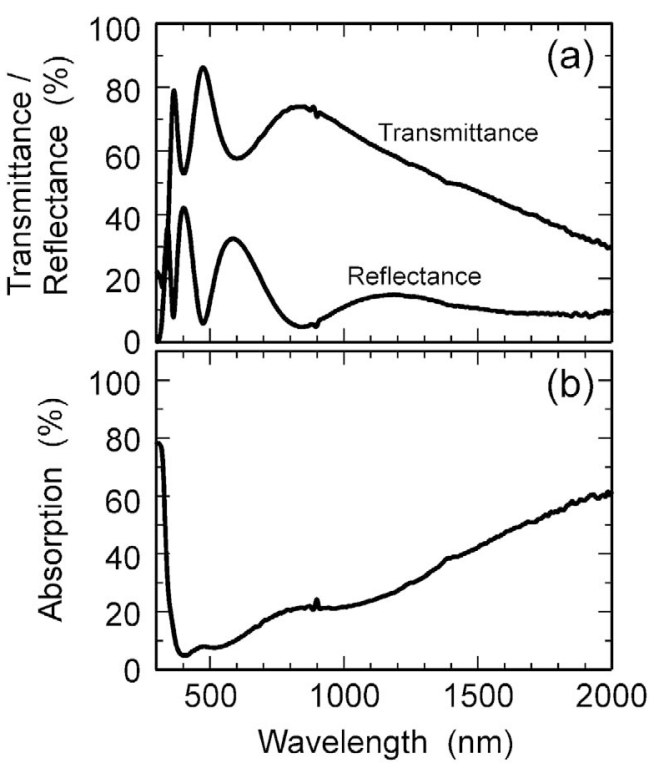

Fig. 8 Optical properties, (a) transmittance and reflectance and (b) absorption of bi-layer TNO film. 
また, 我々は, 電気伝導の異方性についても着目してい る. アナターゼ型構造は異方性を有しているので, 電気伝導 も異方的なはずである。実際，c 軸方向の有効質量が， a 軸 方向の有効質量に比べて，数倍大きいということがわかって きた。したがって，多結晶薄膜とエピタキシャル薄膜との $\rho$ の開きには, 粒界散乱の寄与に加えて, この電気伝導の異方 性が関与している可能性が高い。今後, TNO 多結晶薄膜の 配向性を制御する工夫も必要になってくるであろう。本研究 では，酸化条件で成膜した無配向の TNO 薄膜をシード層と して用いたが，その他の材料でガラス上に配向し易く，か つ，アナターゼとの格子マッチングが良好なものがあれば， それをシード層として採用すれば，配向性を制御すること可 能になるであろう。この方面からもアプローチしていきたい.

以上のような実用的な研究だけでなく, 透明導電性の発現 メカニズム等の基礎的な研究にも取り組んでいく予定であ る. 特に, TNOに打ける電気伝導のメカニズムについて は，不明な点が多々ある。これを解明することができれば， 実用化研究も加速するものと信ずる.

\section{8. おわりに}

スパッタ法を用いてガラス上に形成したアナターゼ型 TNO 多結晶薄膜で，ポストアニール処理をすることなく， $\sim 1 \times 10^{-3} \Omega \mathrm{cm}$ の低い抵抗率を達成できることを紹介し た。低い抵抗率の TNO 多結晶薄膜を得るには，「強く還元 されたアナターゼをつくる」というシンプルな指針に集約さ れる. 本稿で紹介した，TNO シード層を用いる成膜技術も この指針に則っている．今後は，この指針に加え，結晶粒径 の増大と配向性の制御が低抵抗化のキーポイントになってく るものと思われる．この取り組みによって，実用的な $\mathrm{TiO}_{2}$ 系透明導電膜をポストアニールなしで実現できることを期待 している.

$\mathrm{TiO}_{2}$ 系透明導電膜は, 最初の報告から 3 年程度しか経過 しておらず，若い材料である. ITO や $\mathrm{ZnO}$ 系透明導電膜の 研究は 20 年以上の歴史があることを考えると, $\mathrm{TiO}_{2}$ 系透明 導電膜はこれからの成長が楽しみな材料である。低抵抗率の $\mathrm{TiO}_{2}$ 系多結晶薄膜を得るための指針は極めてシンプルであ る. 今後, 数多くの研究者が $\mathrm{TiO}_{2}$ 系透明導電膜に取り組 み，この材料開発が進展することを期待したい.

本稿をまとめるのに当たり，多くの方に御協力を頂きまし た．KASTナノ光磁気デバイスプロジェクトの古林寛, 廣 瀬靖，笠井淳平，中尾祥一郎，山本幸生の各氏をはじめ，同 プロジェクトの方々には, 多大な御協力と貴重なご助言をい ただきました。打礼申し上げます。

\section{〔文献〕}

1) D. S. Ginley and C. Bright: Mater. Res. Bull., 25 (2000) 15.

2) Y. Furubayashi, T. Hitosugi, Y. Yamamoto, K. Inaba, G. Kinoda, Y. Hirose, T. Shimada, and T. Hasegawa: Appl. Phys. Lett., 86 (2005) 252101.

3) T. Hitosugi, Y. Furubayashi, A. Ueda, K. Itabashi, K. Inaba, Y. Hirose, G. Kinoda, Y. Yamamoto, T. Shimada and T. Hasegawa: Jpn. J. Appl. Phys., 44 (2005) L1063.

4) Y. Furubayashi, T. Hitosugi, Y. Yamamoto, K. Inaba, G. Kinoda, Y. Hirose, T. Shimada and T. Hasegawa: Thin Solid Films., 496 (2006) 157.

5) Y. Furubayashi, T. Hitosugi and T. Hasegawa: Appl. Phys. Lett., 88 (2006) 226103.

6) S. X. Zhang, D. C. Kundaliya, W. Yu, S. Dhar, S. Y. Young, L. G. Salamanca-Riba, S. B. Ogale, R. D. Vispute and T. Venkatesan: J. Appl. Phys., 102 (2007) 013701.

7) S. X. Zhang, S. Dhar, W. Yu, H. Xu, S. B. Ogale and T Venkatesan: Appl. Phys. Lett., 91 (2007) 112113

8) M. A. Gillispie, F. A. M. van Hest, M. S. Dabney, J. D. Perkins and D. S. Ginley: J. Appl. Phys., 101 (2007) 033125.

9) T. Hitosugi, A. Ueda, S. Nakao, N. Yamada, Y. Furubayashi, Y. Hirose, T. Shimada and T. Hasegawa: Appl. Phys. Lett., 90 (2007) 212106.

10) N. Yamada, T. Hitosugi, N. L. H. Hoang, Y. Furubayashi, Y. Hirose, T. Shimada and T. Hasegawa: Jpn. J. Appl. Phys., 46 (2007) 5275.

11) N. Yamada, N. L. H. Hoang, J. Kasai, T. Hitosugi, T. Shimada and T. Hasegawa: Tech. Dig. 17th Photovoltaic Science \& Engineering Conf., Fukuoka, Japan, 2007 (Int. PVSEC-17, Fukuoka, 2007) p. 845

12) K. L. Chopra, S. Major and D. K. Pandya: Thin Solid Films, 102 (1983) 1

13) T. Hitosugi, A. Ueda, Y. Furubayashi, Y. Hirose, S. Konuma, T. Shimada and T. Hasegawa: Jpn. J. Appl. Phys., 46 L86 (2007).

14) M. A. Gillispie, M. F. A. M. van Hest, M. D. Dabney, J. D. Perkins and D. S. Ginley: J. Mater. Res., 22 (2007) 2832.

15) S. Y. Guo, W. N. Shafarman and A. E. Delahoy: J. Vac. Sci. Technol A, 24 (2006) 1524.

16) U. Diebold: Surf. Sci. Rep., 48 (2003) 33.

17) H. Tang, K. Prasad, R. Sanjines, P. E. Schmid and F. Lévy: J. Appl. Phys., 75, 2042 (1994).

18) Y. Furubayashi, N. Yamada, Y. Hirose, Y. Yamamoto, M. Otani, T. Hitosugi, T. Shimada and T. Hasegawa: J. Appl. Phys., 101 (2007) 093705

19) H. P. R. Frederiske: J. Appl. Phys., 32 (1961) 2211.

20) S. Schiller, G. Beister, W. Sieber, G. Schirmer and E. Hacker: Thin Solid Films, 83 (1981) 239.

21) D. Wicaksana, A. Kobayashi and A. Kinbara: J. Vac. Sci. Technol. A, 10 (1992) 1479.

22) J. Y. W. Seto: J. Appl. Phys., 46 (1975) 5247.

23) G. E. Jellison, Jr., L. A. Boatner, J. D. Budai, B.-S. Jeong and D. P. Norton: J. Appl. Phys., 93 (2003) 9537.

24) I. Hamberg and C. G. Granqvist: J. Appl. Phys., 60 (1986) R123.

25) H. Natsuhara, K. Matsumoto, N. Yoshida, T. Itoh, S. Nonomura, M. Fukawa and K. Sato: Sol. Energy Mater. Sol. Cells, 90 (2006) 2867. 